\title{
FINANCIAL INDICATORS IN THE SYSTEM OF ECONOMIC SECURITY
} OF THE WORLD COUNTRIES

\author{
Olha Hrybinenko ${ }^{1}$, Olena Bulatova ${ }^{2}$, Olha Zakharova ${ }^{3}$ \\ ${ }^{1}$ Department of Economic of Enterprises, Faculty of Finances and Economics, \\ Dnipro University of Technology, pr. Dmytra Yavornytskoho, 19, Dnipro, Ukraine \\ ${ }^{2,3}$ Economics and International Economic Relations Department, Mariupol State University, \\ Budivelnykiv Ave., 129a, Mariupol, Ukraine \\ E-mails: ${ }^{1}$ hrybinenko.o.m@nmu.one; ${ }^{2}$ olena_bulatova@yahoo.com; \\ 3o.zakharova@mdu.in.ua(correspondingauthor)
}

Received 31 March 2020; accepted 07 May 2020

\begin{abstract}
The paper is aimed at quantitative evaluation of the level of countries' financial solvency based on the use of a multidimensional methodical toolkit for evaluating financial indicators of a country's development, which results in the construction of the appropriate integral security indices. Unlike other methods to assess the level of security, the proposed approach makes it possible to determine not only the integrated level of a financial component of the economic security but also to calculate the quantitative thresholds of the financial indicators aggregated in the integral index (gold and currency reserves, external debt per capita, changes in the official local currency rate, budget deficit/surplus to GDP); going beyond the threshold values is a signal of the increased risk and lack of solvency. Comprehensive consideration of the financial indicators, taken from the official statictic databases or calculated basing on the official statictics, in the structure of the integral index helps quantify the level of a financial component in the system of ensuring countries' economic security. The proposed approach is approbated in terms of the countries for which the level of a component of the financial solvency (critical, dangerous, unsatisfactory, safe, and optimal) has been calculated. From the practical viewpoint, the proposed toolkit makes it possible to identify actual and potential threats to the countries' sustainable development. The obtained integral indices of security can be used as the variables in economic and mathematical models while evaluating the effect of security status on the global economic development and positions of certain countries, communities, and regions in the system of world economic relationships.
\end{abstract}

Keywords: economic security, financial component of economic security, financial indicator, multiple indices, integral security index, risks, threats.

JEL Classification: F30, F52, C10

\section{Introduction}

From the beginning of its functioning, a financial sector has been aimed mostly to serve all other segments of the world economy. In terms of globalization, role of a financial sector in the modern world economy has changed cardinally; the financial market itself has turned into a completely selfsufficient segment of the world economy system where operations are being frequently conducted separately from the real economic sector (Bulatova \& Marena, 2019; Eszter, 2015; Adrian et al., 2019). As a result of considerable mobility of the financial assets, in terms of its scales of financial operations, a financial market starts occupying dominating positions in the world market: according to the experts' estimates, daily amount of operations in the world financial market is more than the world trade operations by 50 times (Sokhatska, 2014).

The scale of operations in the world financial market is proved by the results of their correlation with the scales of the industrial sphere development: volume of the global financial assets is much higher that the volumes of the world GDP; and level of financialization in the recent years is much higher than within the pre-crisis period (International Monetary Fund, 2019; Europaen Central Bank, 2019; Bulatova \& Marena, 2019). There is a growth of nonuniformity of the distribution of financial resources among the world countries and regions on the background of the increasing general level of the world economy financialization. In this context, spatial structure of the global financial assets is characterized by a high concentration level: as of 2017, the USA and the EU accounted for 
about $33 \%$ and $22 \%$ of financial assets respectively (totally, that covers more than a half of the world financial assets) (Bulatova et al., 2019).

Nonuniform distribution of the financial resources among the world countries and regions as well as world industries causes activation of the international capital flows and sharpens competitiveness for its involvement in the form of both borrowed and entrepreneur's capital. Constant redistribution of the financial assets, variability of the transboundary capital flows, activation of the movement of the short-term speculative capital increase disbalance and instability of the balance of payments and act as the risky factors of the financial solvency of the world countries (Caprio, 2012; Bonaparte, 2016).

The processes considered in the mentioned scientific papers and in other studies that dwell upon the problems of economic security (Cook \& Mueser, 2013; Dudin, et al., 2018; Baldwin, 1997; Ronis, 2011; Ackroyd, \& Marsden, 2006; The Security Economy, 2004) actualize a problem of the development of the corresponding toolkit for the evaluation and analysis of financial indicators in the system of international economic security aimed at the provision of sustainable socioeconomic development of the world countries. The theoretical and methodological issues involving analysis of the complex (integral) effect of the financial indicators, which are different in their nature of manifestation, way of representation etc., should be developed in the first turn as those factors play a key role in the system of economic security. Aspects of the substantiation and quntitative identification of the boundary values for the financial indicators included in the system of economic security parameters, which may be considered as the basis for the development of a system for the security monitoring, are still understudied. Timely identification of the deviations of actual values of the financial indicators (their being beyond the threshold ones) will help take into consideration the risks and threats with further prevention of possible risky situations or decrease of the level of their negative effects.

Objective of the research is quantitative evaluation of the level of financial component of economic security on the basis of methodical toolkit of multiple scoring of certain financial indicators of the countries' development which results in the elaboration of corresponding security indices.

\section{Research methodology}

Economic processes taking place in the world economic system are quite complex and multisided. Owing to that fact, if an issue of complex evaluation arises, it may be performed on the basis of the whole system of single indices being different in their statistic nature, way of obtaining, measuring units etc. Possibility of their consideration in the framework of an integral (synthetic) parameter is implemented with the help of methodical toolkit of multiple scoring.

Multiple indices are the most satisfactory toolkit of a comparative analysis which is confirmed by constantly growing amount of those indicators being the basis of different ratings of economic, social, industrial and technological, and ecological development of the countries (OECD, 2008).

The research proposes to apply a methodology of multiple scoring to analyse a level of economic security being a complex category which quantitative scoring should be based on the consideration of the totality of criteria (security indicators).

In this context, there are following basic issues of theoretical and methodological nature which should be studied and substantiated logically:

First is substantiation of the structure of a corresponding security index which means singling out of the components of different orders (subindices or local security indices), determining qualitative and hierarchical dependences, and substantiating expediency of the singling out of different components according to the modern tendencies and regularities of the world economic development.

Second is formation of the system of security indicators (single parameters) which may be classified and systematized properly taking into account the component singled out in p. 1 (subindices). Substantiation of the essence of each indicator from the viewpoint of representation of the security component of the countries' development (i.e. from the viewpoint of independence, sustainability, stability, dynamics of the development of national economies, their protection and competitiveness, ability to counteract the internal and external threats). Consideration of the possibility of parametrization and qualitative scoring of the indicators including certain retrospection period which will help include them in the calculation of the integral index with its further estimation in dynamics taking into account the available data and international sources of statistic information. 
The research proposes to include following parameters as the indicators of a financial component of the security: volume of gold and currency reserves in import months (indicator of the country's debt solvency), level of budget deficil to GDP (indicator of the budget security), index of changes in the national currency rate to USD (indicator of the currency security), level of external debt per capita (indicator of the debt security). First two indicators are the primary ones being published by the international organizations; the latter two are calculated on the basis of the official statistics (IMF, 2020; World Bank, 2020).

Third is systematization of possible parameters concerning their character of influencing on the level of both economic security and its components (subindices); possibilities to single out or calculate normative (threshold, critical, admissible etc.) values which may be applied in the system of monitoring for economic security threats and included in the corresponding mechanisms for providing sufficient level of national economic security; way of expression or representation in the form of statistic values (absolute, relative, medium values; individual or complex indices etc.) which will effect immediately the results of practical calculations.

Taking into consideration the aforementioned, single parameters should be selected basing on their analytical substantiation, measurability, and availability in the corresponding statistic bases in terms of sufficient sampling of the countries (coverage degree), correspondence to the phenomenon being measured (high capability to act as the security level identifier), and relations to each other. Possibilities of the parameters substitution (use of proxy-variables) should be taken into account as the case of nonavailability of some parameters in general or in terms of great amount of the estimation objects (countries).

Forth is determination of the standardizing methods for single parameters which will provide their reduction to the comparable form and make it possible to aggregate to the corresponding structure of the total integral security index.

Theory and practice of current economic analysis have developed and approbated several methods to reduce the parameters, which are different in their way of representation, to the comparable form, i.e. method of ranging, method of standardization (calculation of z-estimates), method of min-max (comparison with the best and the worst values of the parameter), method of comparison with the average parameter value, method of comparison with the highest parameter value, method of category-based scaling, method of cyclic indicators etc. (OECD, 2008; Freudenberg, 2003; Jacobs, Smith, \& Goddard, 2004; Nilsson, 2000). Methods of normalization help transform indicators with different quantities into the nondimensional values and compare differently directed indicators, which is essential to form the integral index; in this context, the methods are based on the comparison of empiric values of the parameter with certain reference value, which may be represented by maximal, minimal, and average value in certain reference (threshold, standard) value of the parameter etc. (Kharazishvili, 2014; Kharazishvili, \& Dron, 2014; Kachinsky, 2013).

Fifth is selection of the corresponding form of an integral (multiple) index (aggregation of the single parameters) and estimation (if necessary) of the weight of certain components of subindices and single parameters they include. Determination of the aggregating and weighing methods.

Sixth is carrying out corresponding empiric calculations on the bases of the formed sampling of countries which level of economic security will be evaluated with the preliminary determination of a retrospection period in terms of which it is possible to accumulate corresponding statistic information and perform corresponding calculations with their further analysis.

To calculate the security indices, typological combined sampling of the world economy countries has been performed; as a result, groups of the countries have been singled out according to their regional features, in terms of which the countries have been divided into 2 groups as for their level of socioeconomic development. The countries were selected in terms of their specific weight in the structure of regional gross domestic product. As a result, the sampling has been formed covering 53 countries divided into 4 groups as for their regional features (America, Europe, Asia and Pacific Islands, Africa and Middle East); each of the group includes both developed and developing countries (Table 1). To provide dynamic comparison and proper evaluation of the intensity and regularities of the security indices dynamics, a retrospection period of 19 years has been specified (2000-2018).

Seventh is calculation of the integral estimates and analysis of the obtained results, i.e. ranking of the countries according to their security level; evaluation of the distribution of the countries according to their security level; calculation of the indices of descriptive statistics and evaluation of nonuniformity of the countries' development according to the corresponding integral estimates; classification of the countries according to their 
security level; identification of the correlations between components and single parameters; specification of the most weighty security indicators etc.

To evaluate the functionality and efficiency of the proposed analysis toolkit, they have been tested in terms of the estimation of a financial component in the system of economic security of the countries on the basis of the algorithm represented in Figure 1 .

Table 1. Sampling of countries for estimation (authors' development)

\begin{tabular}{|c|c|c|}
\hline \multirow{2}{*}{ Region } & \multicolumn{2}{|c|}{ Level of development } \\
\hline & Developed & Developing \\
\hline America & USA, Canada & $\begin{array}{l}\text { Argentina, Bra- } \\
\text { zil, Chili, Co- } \\
\text { lumbia, Cuba, } \\
\text { Mexico, Peru, } \\
\text { Venezuela }\end{array}$ \\
\hline Europe & $\begin{array}{l}\text { Germany, Great Brit- } \\
\text { ain, France, Italy, } \\
\text { Spain, Netherlands, } \\
\text { Switzerland, Poland, } \\
\text { Sweden, Belgium, } \\
\text { Austria, Norway, } \\
\text { Denmark,Finland, } \\
\text { EU28 }\end{array}$ & Ukraine, Russia \\
\hline $\begin{array}{l}\text { Asia } \\
\text { and } \\
\text { Pacific }\end{array}$ & $\begin{array}{l}\text { Japan, Australia, New } \\
\text { Zealand }\end{array}$ & $\begin{array}{l}\text { China, India, } \\
\text { Korea, Indonesia, } \\
\text { Thailand, Malay- } \\
\text { sia, Singapore, } \\
\text { Philippines }\end{array}$ \\
\hline $\begin{array}{l}\text { Africa } \\
\text { and } \\
\text { Middle } \\
\text { East }\end{array}$ & Israel & $\begin{array}{l}\text { Turkey, Iraq, } \\
\text { Egypt, Saudi } \\
\text { Arabia, Yemen, } \\
\text { Qatar, Bahrain, } \\
\text { Kuwait, UAE, } \\
\text { Nigeria, South } \\
\text { Africa, Algeria, } \\
\text { Morocco, Angola }\end{array}$ \\
\hline
\end{tabular}

Contrary to the available ones, the author's approach to the development of a methodological toolkit for quantitative evaluation and analysis of a financial component of economic security of the countries, which describes the proposed algorithm, is based on the following points:

- firstly, economic security is a complex concept which evaluation should be based on the consideration of the comprehensive evaluation criteria (security indicators). Due to that fact, quantitative evaluation of the security level is possible by applying multiple scoring methodology, which re- sults in the construction of corresponding integral security.

- Secondly, the constructed security index shoul not only have the nature of a descriptive parameter, which aggregates a system of single quantitative parameters in the integrated complex evaluation, but it should also act as a certain criterion, which, according to the specified conditions, has a range of variations; if the value is beyond the range, that is the signal of changes in the security level and identification of the risks intensification or growing threats for the security.

- thirdly, that provides the possibility of quantitative estimation of the security level owing to the financial parameters; it helps represent the sustainability level and classify the countries in terms of their security level.

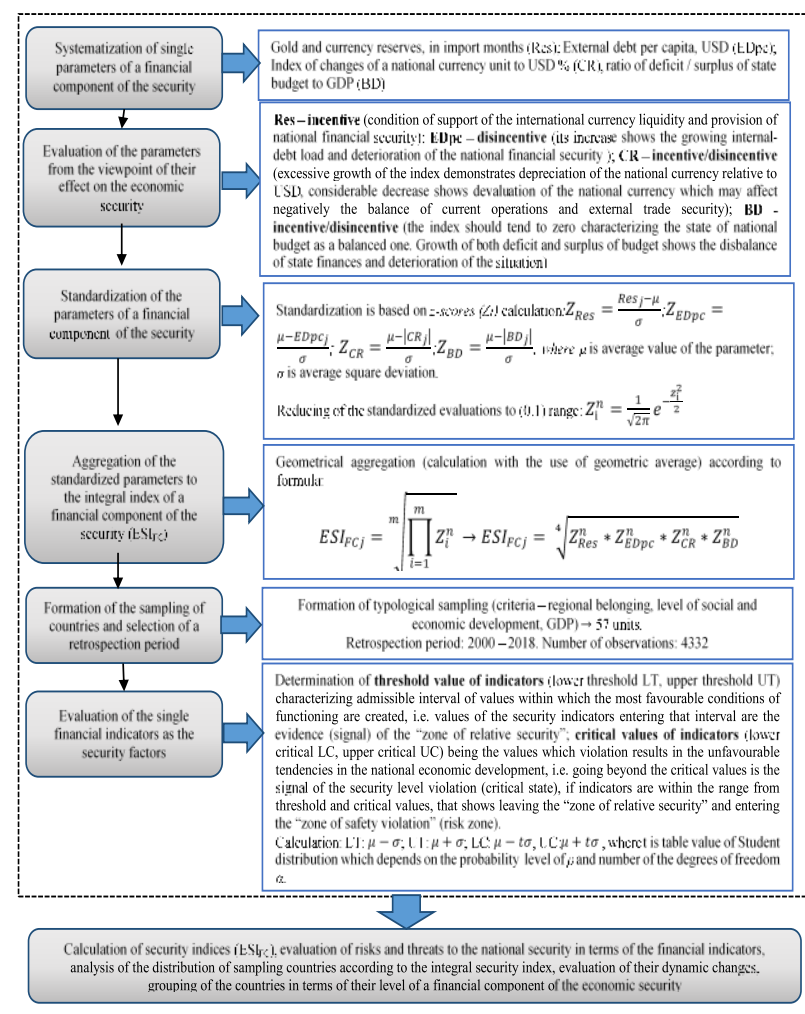

Figure 1. Algorithm of multiple scoring of the level of a financial component of the economic security of the countries (complied by the authors)

\section{Results}

Financial solvency is the most complex component of the economic security characterizing the situation when the required financial conditions are being developed and provided for sustainable social and economic development; stability of national 
economy is being provided as for financial disbalances and financial crises (He, 2016; Redo, 2018; The Global Risks Report, 2020). Financial solvency combines debt, budget, currency, money and credit components; thus, the research involves one indicator from each component of the financial solvency

Average worldwide index of gold and currency reserves in the import months (Figure 2) was characterized by its growth tend during 2000-2009 (there was the increase by almost three times from 5.52 up to 15.54) and had a reverse trend in 20092018 (there was the decrease by $40 \%$ down to 10.8 in 2018).

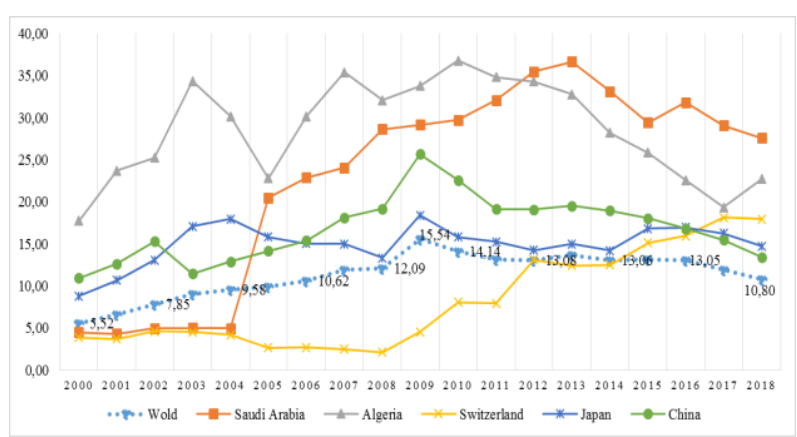

Figure 2. Dynamics of the index of gold and currency reserves in the import months in the world and countries with the highest level in 2000-2018 (source: World Bank, 2020)

Saudi Arabia is characterized by the highest level of the index (27.6 in 2018) and the most intense growth rate during the analyzed period (increase by 6.2 times compared to 2000). Indices for Switzerland have increased by 4.6 times (17.95 in 2018). Algeria is characterized by the value of 22.7 being higher than the level of 2000; however, it demonstrates year-by-year decrease beginning from 2007 (maximum level is 35.4). Gold and currency reserves of Japan are 14.75 of the import months; China shows the value of 13.41 characterized by the same dynamics as the average worldwide index.

Concerning the level of external debt of the countries, Figure 3 represents TOP20 of the countries-biggest debtors in the world according to the data by 2018 .

Thus, those are the developed countries ( 17 of the 20 represented ones) that are the biggest debtors; debt level of the three of them (the Netherlands, Singapore, and Switzerland) is more than USD 200000 per capita (being by 1000 times higher than the critical values taken by the world practice). During that period, debt level of those countries has increased twice in the Netherlands and Singapore; in Switzerland it has increased by 2.8 times. Four EU countries (Great Britain, Belgium, Finland, Sweden, and Norway) have debt level of more than USD 100000 per capita. Calculation of the average value of the debt level in terms of the sampling under analysis has demonstrated that the indicator value has the strongly marked growth trend: in 2018, the figure is USD 42000 per capita being by almost 2.5 times higher than the level of 2000.

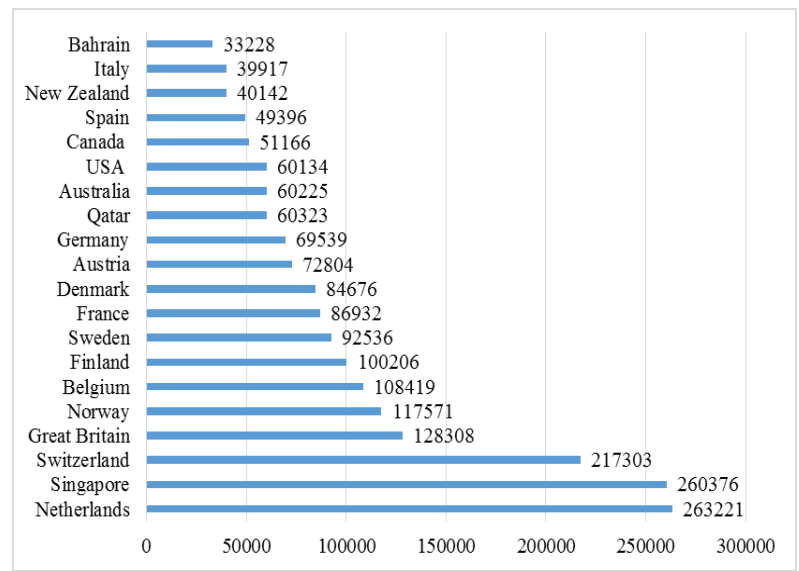

Figure 3. Distribution of the world countries in terms of their level of external debt per capita (2018) (source: World Bank, IMF, 2020)

As for the indicator of budget security, following countries belong to the ones with the highest level of budget deficit relative to the GDP: Venezuela $(-30.56 \%$ in 2018 , deficit was observed during the whole period of 2009-2018), Cuba (-8.1\%), Brazil $(-7.1 \%)$, Saudi Arabia (-9.2\%), and Egypt (-8.2\%); Kuwait (11.4\% in 2018) and Norway $(8.12 \%)$ are the countries with the highest budget surplus level. Such developed countries of European region as Austria, Poland, Denmark, Belgium, Finland, and Sweden (plus Singapore and Canada from other regions) belong to the ones with the most balanced level of state finances.

Table 2 represents the results of calculations of boundary values of financial indicators as factors in the security system.

Thus, threatening levels of the amounts of gold and currency reserves in the import months were defined as 1.54 in 2018 (lower critical), being by $13.2 \%$ higher than the level of 2000 , and $5.15 \%$ (lower threshold), being by 2.46 times higher than the level of 2000. Safe level was defined as 16.46 in 2018 (upper threshold), being higher that the level of 2000 by $83.9 \%$ but lower than the level of 2012, and 22.15 (upper critical), being higher by $78.6 \%$ than the level of 2000. Upper threshold val- 
ues are the indicators which exceedance shows much higher stability of the financial system.

As for the debt level, all the boundary values are characterized by the growth trend; average worldwide level of the external debt per capita has increased by $144.5 \%$ from USD 17520 in 2000 up to USD 42840 in 2018. Exceedance of those levels develops conditions for increasing risks for the security. Lower critical value is estimated as USD 135 in 2018 (increase by $40.9 \%$ compared to 2000), lower threshold value is USD 3286 in 2018 (increase by $146.2 \%$ ). Indicator of insecure level is the exceedance of the debt index at the boundary of USD 105700 (upper threshold value in 2008), being by $122.9 \%$ more than the estimate of 2000 ; indicator of critical level is more than USD 169100 (upper critical value in 2018), being by $118 \%$ higher than the level of 2000.

Table 2. Dynamics of the boundary values of financial indicators in the system of security of the world countries within the period of 2000-2018 (authors' calculations)

\begin{tabular}{|c|c|c|c|c|}
\hline \multirow{2}{*}{ Indicator } & \multirow{2}{*}{$\begin{array}{c}\text { Bounda- } \\
\text { ry val- } \\
\text { ues } \\
\end{array}$} & \multicolumn{3}{|c|}{ Years } \\
\hline & & 2000 & 2008 & 2018 \\
\hline \multirow{5}{*}{$\begin{array}{l}\text { Gold and } \\
\text { currency re- } \\
\text { serves, in } \\
\text { import } \\
\text { months }\end{array}$} & AWT & 5.52 & 12.09 & 10.80 \\
\hline & LC & 1.36 & 1.64 & 1.54 \\
\hline & $\mathrm{LT}$ & 2.09 & 5.75 & 5.15 \\
\hline & UT & 8.95 & 18.43 & 16.46 \\
\hline & UC & 12.40 & 24.82 & 22.15 \\
\hline \multirow{5}{*}{$\begin{array}{l}\text { External debt } \\
\text { per capita, } \\
\text { USD }\end{array}$} & AWT & 17522 & 41895 & 42836 \\
\hline & LC & 96 & 87 & 135 \\
\hline & $\mathrm{LT}$ & 1335 & 1991 & 3286 \\
\hline & UT & 47435 & 105719 & 105743 \\
\hline & $\mathrm{UC}$ & 77547 & 169967 & 169067 \\
\hline \multirow{5}{*}{$\begin{array}{l}\text { Index of } \\
\text { changes in the } \\
\text { official na- } \\
\text { tional mone- } \\
\text { tary unit to } \\
\text { USD, } \%\end{array}$} & AWT* & 0 & 0 & 0 \\
\hline & LC & -71.15 & -12.22 & -26.25 \\
\hline & LT & -35.46 & -6.09 & -13.08 \\
\hline & UT & 35.46 & 6.09 & 13.08 \\
\hline & $\mathrm{UC}$ & 71.15 & 12.22 & 26.25 \\
\hline \multirow{5}{*}{$\begin{array}{l}\text { Ratio of defi- } \\
\text { cit / surplus of } \\
\text { state budget to } \\
\text { GDP, \% }\end{array}$} & AWT* & 0 & 0 & 0 \\
\hline & LC & -15.84 & -14.05 & -10.86 \\
\hline & $\mathrm{LT}$ & -7.90 & -7.00 & -5.41 \\
\hline & UT & 7.90 & 7.00 & 5.41 \\
\hline & $\mathrm{UC}$ & 15.84 & 14.05 & 10.86 \\
\hline
\end{tabular}

Note: AWT - average world threshold, LC - lower critical, LT lower threshold, UT - upper threshold, UC - upper critical; ${ }^{*}$ average values are replaced by zero values of the parameter representing optimal values of the parameter.

Range of volatility of the national currency rate in both directions is evaluated at the level of $\pm 13.08 \%$ (threshold in 2018) and $\pm 26.25 \%$ (critical in 2018). In general, intensity of the rate change is characterized by its deceleration; boundary values decreased by $63.1 \%$ within the period of 2000 2018. Boundary values of deficit/surplus of the state budget in the GDP are evaluated at the level of $\pm 5.41 \%$ (threshold in 2018) and $\pm 10.86 \%$ (critical in 2018); in this context, dynamics of the boundary values is characterized by the reducing range of deviation during $2000-2018$ by $31.5 \%$.

Table 3 represents the results of evaluation of the countries' being in different security zones in terms of the analyzed financial indicators.

Table 3. Evaluation of the risks and threats to the countries' security in terms of the financial indicators (authors' calculations)

\begin{tabular}{|c|c|c|}
\hline \multirow[b]{2}{*}{ Indicators } & \multicolumn{2}{|c|}{2018} \\
\hline & $\begin{array}{c}\text { Zone of relative } \\
\text { danger (risks): UT- } \\
\text { UC, LC-LT, } \\
\text { <AWT, >AWT }\end{array}$ & $\begin{array}{l}\text { Zone of criti- } \\
\text { cal danger } \\
(<\mathrm{LC},>\mathrm{UC})\end{array}$ \\
\hline $\begin{array}{l}\text { Gold and cur- } \\
\text { rency reserves, } \\
\text { in months } \\
\text { (Res) }\end{array}$ & $\begin{array}{l}21 \text { countries } \\
(39.6 \%) \\
\text { LC-LT: Chile, } \\
\text { Mexico, Venezuela, } \\
\text { Great Britain, } \\
\text { France, Italy, Spain, } \\
\text { Poland, Sweden, } \\
\text { Norway, Denmark, } \\
\text { UN28, Ukraine, } \\
\text { Australia, New } \\
\text { Zealand, Malaysia, } \\
\text { Turkey, Qatar, } \\
\text { UAE, RSA, Moroc- } \\
\text { co }\end{array}$ & $\begin{array}{l}9 \text { countries } \\
(17.0 \%) \\
\text { <LC: the } \\
\text { USA, } \\
\text { Canada, } \\
\text { Germany, the } \\
\text { Netherlands, } \\
\text { Belgium, } \\
\text { Austria, Fin- } \\
\text { land, Yemen, } \\
\text { Bahrain }\end{array}$ \\
\hline $\begin{array}{l}\text { External debt } \\
\text { per capita, } \\
\text { USD (ExtDpc) }\end{array}$ & $\begin{array}{l}2 \text { countries }(3.8 \%) \\
\text { UT-UC: Belgium, } \\
\text { Great Britain }\end{array}$ & $\begin{array}{l}3 \text { countries } \\
(5.7 \%) \\
>\text { UC: the } \\
\text { Netherlands, } \\
\text { Switzerland, } \\
\text { Singapore }\end{array}$ \\
\hline $\begin{array}{l}\text { Index of } \\
\text { changes in the } \\
\text { official rate of } \\
\text { national cur- } \\
\text { rency to USD, } \\
\%(\mathbf{C R})\end{array}$ & $\begin{array}{l}1 \text { country }(1.9 \%) \\
\text { LC-LT, UT-UC: } \\
\text { Brazil }\end{array}$ & $\begin{array}{l}3 \text { countries } \\
(5.7 \%) \\
<\mathrm{LC},>\mathrm{UC} \text { : } \\
\text { Argentina, } \\
\text { Turkey, An- } \\
\text { gola }\end{array}$ \\
\hline $\begin{array}{l}\text { Ratio of deficit } \\
\text { / surplus of } \\
\text { state budget to } \\
\text { GDP, \% (BD) }\end{array}$ & $\begin{array}{l}8 \text { countries }(15.1 \%) \\
\text { LC-LT, UT-UC: } \\
\text { the USA, } \\
\text { Argentina, Brazil, } \\
\text { Cuba, Norway, } \\
\text { Iraq, Egypt, Saudi } \\
\text { Arabia }\end{array}$ & $\begin{array}{l}2 \text { countries } \\
(3.8 \%) \\
<\text { LC, > UC: } \\
\text { Venezuela, } \\
\text { Kuwait }\end{array}$ \\
\hline
\end{tabular}

Thus, most countries represented by mostly developed ones are within the insecure zone in 
terms of the first two indicators. If in 2000, in terms of the level of gold and currency reserves, $28.3 \%$ of the countries were included into the risky zones, in 2018 the share increased up to $56.6 \%$. According to the debt level, $14.1 \%$ of the sampling countries (developed ones) in 2000 and $9.5 \%$ of them in 2018 were in different insecure zones. Level of the national currency volatility to USD remains relatively moderate in case of the absolute majority of the countries (within the range of boundary values); only four countries (Turkey, Angola, Brazil, and Argentina) entered the risk zone.

As for the level of budget deficit/surplus to GDP, $9.5 \%$ of the sampling countries in 2000 and $18.9 \%$ of them in 2018 were in different insecure zones. Contrary to the first two indicators, those countries are mostly the developing ones except Norway and the USA (in 2018). Generally, the indicator data have helped identify the tendency to expansion of the security risk effect.

Figure 4 represents a rating of the countries in terms of their integral level of a financial component of the security formed as a result of calculation of the corresponding subindices in dynamics within the period of 2000-2018.

Such countries as China, Peru, Japan, Israel, Algeria, Russia, Iraq, Korea, Columbia (mostly, developing countries) got the highest integral estimates in terms of the financial solvency according to the data by 2018. Singapore, Angola, the Netherlands, Argentina, and Venezuela got the lowest integral estimates (according to the results of calculation of boundary values, those countries were in the zone of critical danger).

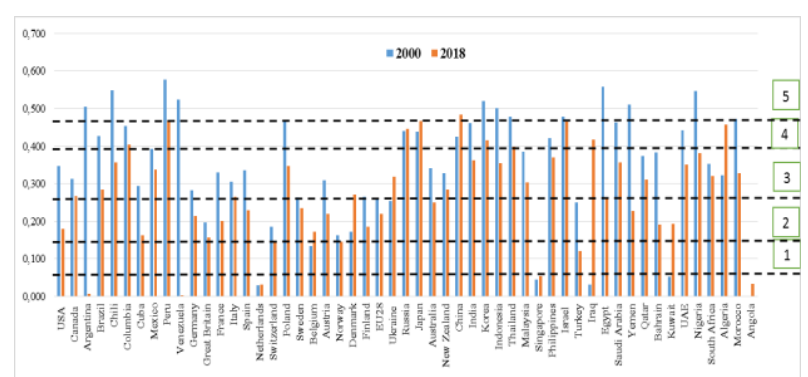

1 - low critical value, 2 - low threshold value, 3 - middle level, 4 - high threshold value, 5 - high critical value (2018)

Figure 4. Distribution of the world countries in terms of the integral level of a financial component of the security (authors' calculations)

Generally, it is possible to speak about overall trend to the decrease of the financial solvency level which is proved by the fact that in case of $79.2 \%$ of the sampling countries, reducing integral estimates in terms of the component is observed. Maximal decrease rates and, correspondingly, loss of positions in the comparative distribution of the countries have been obtained for such countries as Argentina $(-98.8 \%$, drop from position 8 down to position 52 ), Venezuela ( $-99.4 \%$, from 5 down to 53), Egypt (-53.1\%, from 2 down to 30$)$, the USA (-48.2\%, from 28 down to 42), and Bahrain ( $-50 \%$, from 25 down to 40 ). Among the rest $20.8 \%$ of the sampling countries which demonstrate the increasing level of financial solvency, following countries demonstrate the highest rates of the integral estimate increment with the considerable changes in rating their positions: China $(+13.8 \%$, from position 21 up to position 1$)$, Iraq (by 12.5 times, from 51 up to 7), Algeria (+41.6\% from 19 up to 3), Denmark ( $+57.7 \%$, from 46 up to 27), Ukraine ( $+25 \%$, from 42 up to 22$)$, and Japan (+6.3\%, from 19 up to 3); Kuwait, Angola, and Singapore also show high growth rates, but that did not result in any changes of their low positions in the rating.

The results of countries' grouping according to the estimates of their financial solvency show that only $17 \%$ of the countries are in the safe zone, i.e. China has optimal level of the indicator among the countries. $32.1 \%$ of the countries belong to the group with satisfactory security level formed by mostly developing countries. $37.7 \%$ of the countries, being mostly developed ones, have unsatisfactory security level. $13.2 \%$ of the countries, according to the integral estimates, have the most insecure level of development from the viewpoint of financial stability and security.

\section{Conclusions}

The world economy demonstrates constant unequal redistribution of the financial resources among the countries; that not only sharpens their business competition for capital raising but also increases the level of financial instability and becomes a risky factor for economic security of the world countries. Constant monitoring and evaluation of the financial indicators in the system of global economic safety, determination of their boundary values help consider risks and threats and, as a result, prevent possible risky situations or reduce the level of their negative effects.

Economic, social, and ecological components of the security are separate constituents of the general level of economic security. Financial solvency is the most complex component of the economic security characterizing the state at which the required financial conditions are developed and provided to stable social and economic development 
along with the stability of national economy as for financial disbalances and financial crises. Financial solvency combines debt, budget, currency, and money and credit components.

The developed countries are characterized by much higher level of economic security (on average, by $26.3 \%$ higher) relative to the group of the developing countries; however, in this context, security indices of the developing country of Asian region exceed the corresponding estimates of the developed countries (on average, by 11\%). The lowest security estimates are obtained for the developing Latin American countries; beginning from 2012, their security level became lower relative to the developing countries of African and Middle East regions. Comparison of the dynamics of integral indices makes it possible to make conclusions on the growth trend in changes in the security level of Asian countries (3.1\% within the period of 2000-2018) and countries of African and Middle East regions (7.4\% of the growth), and the decrease trend in the developed countries in general (14.5\% of the decrease) and the developing Latin American countries (26.3\% of the decrease).

The proposed toolkit for evaluation and analysis of the level of international economic security has made it possible to perform complex analysis of the regularities of economic factors in the system of formation and provision of the sustainable social and economic development of the world countries. The calculated indices of a financial component of the economic security have helped range the countries and classify them in the groups, i.e. the countries with critical, dangerous, unsatisfactory, satisfactory, and optimal security level. The majority of the countries are in the dangerous zones in terms of their financial indicators.

\section{References}

Ackroyd, P., \& Marsden, S. (2006). Enhancing security culture - simple, effective approaches to making improvement. Greenstreet Berman.

https://www.icheme.org/communities/subject_grou ps/security $\% 20$ and $\% 201$ loss $\% 20$ prevention/resourc es/hazards\%20archive/ /media/Documents/Subjec t\%20Groups/Security_Loss_Prevention/Hazards\% 20Archive/XIX/XIX-Paper-32.pdf

Adrian, T., He, D., Liang, N., \& Natalucci, F. M. (2019). A monitoring framework for global financial stability. IMF Staff Discussion Notes 19/06, International Monetary Fund. https://doi.org/10.5089/9781498300339.006

Baldwin, D. (1997). The concept of security. Review of International Studies, 23, 5-26. https://www.princeton.edu/ dbaldwin/selected $\% 20$ articles/Baldwin\%20\%281997\%29\%20

The $\% 20$ Concept $\% 20$ of\%20Security.pdf

Bonaparte, Y. (2016). Global Financial Stability Index. https://ssrn.com/abstract=2753667

Bulatova, O., Shabelnyk, T., Marena, T., \& Reznikova, N. (2019). Influence of regional financial market models on the structure of global financial assets. Advances in Economics, Business and Management Research: Proceedings of the 6th International Conference on Strategies, Models and Technologies of Economic Systems Management, Vol. 95 (pp. 281-285). Atlantis Press. https://doi.org/10.2991/smtesm-19.2019.55

Bulatova, O., \& Marena, T. (2019). World banking system: post-crisis recovery? Journal of European Economy, 18(3), 321-337. https://doi.org/10.35774/jee2019.03.321

Caprio, G. (2012). Handbook of safeguarding global financial stability. Political, Social, Cultural, and Economic Theories and Models (754 p.). Academic Press.

Cook, J. A., \& Mueser, K. T. (2013). Economic security: An essential component of recovery [Editorial]. Psychiatric Rehabilitation Journal, 36(1), 1-3. https://doi.org/10.1037/h0094739

Dudin, M., Fedorova, I., Ploticina, L., Tokmurzin, T., Belyaeva, M., \& Ilyin, A. (2018). International practices to improve economic security. European Research Studies Journal, XXI(1), 459-467. https://doi.org/10.35808/ersj/962

European Central Bank. (2019). Special feature: climate change and financial stability. Financial Stability Review. Frankfurt.

Freudenberg, M. (2003). Composite indicators of country performance: a critical assessment. OECD, Paris.

He, D. (2016). Financial security in China: situation analysis and system design (224 p.). Springer.

International Monetary Fund. (2019). Global financial stability report: lower for longer. Washington, DC, October.

International Monetary Fund. (2020). IMF Data. https://www.imf.org/en/Data

Jacobs, R., Smith, P., \& Goddard, M. (2004). Measuring performance: an examination of com performance indicators. Centre for Health Economics. Technical Paper, Series 29.

Kachinsky, A. (2013). National Security Indicators: defining and applying their limit values: monograph (104 p.). NISD.

Kharazishvili, Y. (2014). Methodological approaches to economic security evaluation. Science and Science of Science, 4, 44-58.

http://dspace.nbuv.gov.ua/handle/123456789/86086

Kharazishvili, Y., \& Dron, Y. (2014). Predicting indicators, thresholds and the level of economic security 
of Ukraine in the medium-term perspective (117 p.). NISD.

Marena, T., \& Peronko, A. (2019). Development of scientific and methodical approaches to the assessment of the Debt Security of Ukraine. MSU Messenger, 18, 79-86. Series: Economy.

Nilsson, R. (2000, 10-14 October). Confidence indicators and composite indicator. CIRET Conference. Paris.

OECD. (2008). Handbook on constructing composite indicators. Methodology and user guide. OECD. https://www.oecd.org/sdd/42495745.pdf

Redo, M. (2018). Comparison of external exposure of Central and Eastern-European states as a factor threatening financial security of their economies. Historia i Polityka, 24, 135-159. https://doi.org/10.12775/HiP.2018.017

Ronis, R. Sh. (2011). Economic security: neglected dimension of national security. National Defense University Press.

https://ndupress.ndu.edu/Portals/68/Documents/Bo oks/economic-security.pdf
Sokhatska, O. (2014). Financization of the world economy. In New World Economic Order and Global Challenges for Ukraine (monograph) (504 p.). V. Koziuk, A. Krysovatyi, \& Ye. Saveliev (Eds.), under the scientific editorshipoof Prof. A. Krysovatyi and Ye. Saveliev. TNEU.

Solt, E. (2015). The quest for the stability of the global financial system. Procedia Economics and $\mathrm{Fi}$ nance, 34, 485-492. https://doi.org/10.1016/S2212-5671(15)01658-5

Stefan, A., Bruno, V., Koch, C., \& Shin, H. S. (2018). The dollar exchange rate as a global risk factor: evidence from investment. BIS Working Paper 695, Bank for International Settlements, Basel.

The Global Risks Report. (2020). World economic forum.

http://www3.weforum.org/docs/WEF_Global_Risk _Report_2020.pdf

The Security Economy. (2004). OECD. https://www.oecd.org/futures/16692437.pdf

World Bank. (2020). Open data. https://data.worldbank.org/ 